\title{
A hybrid analytical network process and fuzzy goal programming for supplier selection: A case study of auto part maker
}

\author{
Hessam Zandhessami $^{\mathbf{a}^{*}}$, Mohammad Ali Afshari ${ }^{\mathrm{b}}$, Seyed Ali Ayazi ${ }^{\mathrm{c}}$ and Javad Siahkali Moradi ${ }^{\mathrm{d}}$
}

${ }^{a}$ Industrial Management Department, Islamic Azad University, Qazvin Branch, Qazvin, Iran

${ }^{b}$ Department of Accounting and Management, Islamic Azad University, Qazvin Branch, Qazvin, Iran

${ }^{c}$ Department of Management, Allame Tabatabaei University, Tehran, Iran

${ }^{d}$ Department of Management and Economy, Science and Research Branch, Islamic Azad University, Tehran, Iran

\begin{tabular}{l}
\hline A R T I C L E I N F O \\
\hline Article history: \\
Received February 25, 2011 \\
Received in Revised form \\
May, 4, 2011 \\
Accepted 4 May 2011 \\
Available online \\
5 May 2011 \\
\hline Keywords: \\
Supplier selection \\
Supply Chain Management \\
Analytic Network Process \\
Fuzzy Goal Programming \\
Factor Analysis
\end{tabular}

\section{A B S T R A C T}

The aim of this research is to present a hybrid model to select auto part suppliers. The proposed method of this paper uses factor analysis to find the most influencing factors on part maker selection and the results are validated using different statistical tests such as Cronbach's Alpha and Kaiser-Meyer. The hybrid model uses analytical network process to rank different part maker suppliers and fuzzy goal programming to choose the appropriate alternative among various choices. The implementation of the proposed model of this paper is used for a case study of real-world problem and the results are discussed.

(C) 2011 Growing Science Ltd. All rights reserved.

\section{Introduction}

Today, most of companies attend to this point that effective supply chain management can be one of the most important instruments to increase competitive advantage. Therefore, creation of subfigures and stable relationships among suppliers and buyers as well as being success in selecting supplier can be the main factor for the success of supply chain. Assessment and selection of suppliers play the most important role in supply chain and it is very necessary for the success of industrial organization (Hartley \& Choi, 1996; Deagraeve et al., 2000). This issue is important because sold goods and services have direct relationship with purchased materials and services. Traditionally, suppliers are selected based on the ability to represent concerned quality, time of delivery and suggestive price (Sevkli et al., 2007). With such process, sellers will offensively compete and relationships among buyers and sellers are completely competitive. In the past, there was more attention on financial statements once a vendor was selected. In such process, the primary aim of buyers is more on the lowest price to increase the competition in the market. However, in today modern organizations, most organizations prefer to use new suppliers' strategy (Chandra \& Kumar, 2000).

\footnotetext{
* Corresponding author. Tel. +989123931628

E-mail addresses: h.zand@qiau.ac.ir (H. Zandhessami)

(C) 2011 Growing Science Ltd. All rights reserved. 
In fact, this strategy means that buyer can have long time relationship and cooperation with limited numbers of suppliers (Koh et al., 2007). A good cooperation among buyers and suppliers is the initial step for establishing successful serial supply. This matter is very necessary but is not enough since we need cooperation and coordination among buyers and suppliers. This cooperation include flow of special working, sharing information through electric communication of data and internet, common programming and other mechanisms organizing production systems of just in time (JIT) and total quality management (Spekman et al., 1998).

The matter of selecting supplier usually involves more than one criterion and criteria are often against each other (Yang et al. 2008). Hence, in order to select supplier, we need an instrument, which can perform this important case regarding multi criteria. Extra to selection of suitable supplier, theoretical methods of decision making can be used in order to assess relationships between buyer and supplier. In the matter of multi criterion decision making, some of alternatives regarding several indices are analyzed and its output is to prioritize them. Different factors are used as the criteria of selecting supplier are: price, approach of just in time delivery, known in industry, size of organization, geographical location, and quality, evaluation of environment, capacity, services, and delay in delivering good, packing, transportation and storing, etc.

In this research, we pay attention to select the final supplier through representing hybrid approach of analytical network and fuzzy-goal programming. This research is fulfilled in one of providing factories of automotive part maker to improve administrative situation of organization. In the next section, we attend to the literature of research and perform researches in the field of selecting supplier. Then, in the third section, we present a methodology and hybrid model and we will finally analyze, conclude and represent operational suggestions.

\section{An overview of literature of research}

\subsection{Supply chain management}

Supply chain management includes unification of supply chains activities and information flows associated with improvement of relationships of chain in order to achieve unfailing competitive benefits. Thus, supply chain management includes process of unifying activities of supply chain and information flows through improvement and unification of activities in supply chain of production and supply of goods (Hull et al., 1999). With increase of competition in the global field, companies should focus on speed and carefulness in answering customer's needs and deliberate for customer's satisfaction and it is a primary focus of this research. Performed attempts in supply chain reduce risk and uncertainty and improve representation of service to customer, improvement of stock levels, processes of business and time cycles and finally increase competition, customer's satisfaction and benefits (Chou \& Chang, 2008). Supply chain management is a process of programming, administration and control of operating supply chain with operational methods (Stevenson, 2002). Limit of supply chain management involves transposition, stock of raw materials, stock of producing goods and produced goods from the primary point to the consumed point. The most important members of supply chain are suppliers; producers and customers that supply chain management follow to establish relationships among them. Communications in supply chain are performed by several ways. In fact, these relationships are associated with three types of flow in supply chain (Stevenson, 2002).

\subsubsection{Physical flow of materials}

Physical flow of materials is movement of raw materials, processing of raw materials and its movement by distributors towards final customers. In this type of flow, physical movement of materials is from high level to low level. 


\subsubsection{Flow of information or communication of information}

In this type of flow, information is transacted among members of supply chain. Movement of information in supply chain is bilateral, meaning that it is fulfilled from high level to low level and vice versa.

\subsubsection{Financial flow or cash flow}

Creation of financial flows is the principle motivation in supply chain and it is performed from low level to high level. During current periods, usage of supply chain has had many benefits for organization that we refer to the following cases:

1) Reduction of stock;

2) Reduction of production costs;

3) Productivity increscent;

4) More agility;

4) Orders time reduction;

5) Customer's more honesty.

One of important tasks in supply chain is decision making in purchasing or producing. There are six important processes in decision making about purchasing or producing which are as follows,

1. Production or purchase,

2. Selection of supplier,

3. Contract and discussion,

4. Designing cooperation,

5. Procurement,

6. Sourcing analysis.

\subsection{Supplier selections and operational models}

There are different works focused on selection of supplier process and various models have been proposed such as goal programming, ratio of benefit to cost, integer programming, multi objective programming and linear programming (Ghodsypour \& O'Brien, 1998; Yan et al., 2003; Oliveria \& Lourenc, 2002). Mikhailov (2002) presented a fuzzy approach in order to select supplier in virtual organizations. He extended analytical hierarchy procedure (AHP) by data fuzzification. Lin \& Chen (2004) used frame of fuzzy decision making for selecting suitable supplier. Onut et al. (2009) used hybrid method of decision making of fuzzy multi criterion in order to select supplier and establish long time relations with them. They used two methods of fuzzy TOPSIS and fuzzy ANP in this direction. In this research, weight of criteria was achieved from fuzzy ANP method in order to select supplier and fuzzy TOPSIS was used in order to evaluate them. Vinodh et al. (2011) defined five groups of criteria in order to select supplier in a productive company where each criterion has sub criteria (Vinodh et al., 2011).

Saaty (2004) used fuzzy AHP model for selecting supplier and designed a model to select the criteria. He analyzed the selection of supplier to a controllable hierarchy in order to distinguish concerned priorities and determined four groups of criteria namely benefits, opportunities, cost (Saaty 2004). 
We can say that the process of selecting supplier is multi objective and multi attribute decision making. While advanced contexts in the management of materials, management of quality, transportation, logistics, achievement to the aims of on time production are prepared, organizations need to cooperate with distributors who can produce qualitative goods (Sevkli et al., 2007). Amin and Razmi used fuzzy QFD technique for supplier selection (Amin \& Razmi 2009). By compounding previous extensive researches, Stuart and McCutcheon (2000) created a model to determine the important factors that are effective in introduction supplier (Stuart \& McCutcheon, 2000). Bevilacqua (2006) represented an algorithm in order to select supplier by QFD fuzzy technique. In this research, the following 8 steps were used for selecting supplier (Bevilacqua 2006).

1. Recognition of characteristics of the goods to be purchased,

2. Recognition of criteria related with assessment of supplier,

3. Determination of the weight of every one of arguments (why),

4. Determination of the relationship between arguments (why) and status (how) of production needs,

5. Determination of weight of status,

6. Preparation of matrix of internal dependencies,

7. Determination of the effect of potential suppliers on the concerned characteristics,

8. Final arrangement on the basis of suitable fizzy index

By AHP fuzzy technique, Lee selected suppliers of a productive company on the basis of hierarchy of represented criteria by Saaty (2003) model. This hierarchy involved three groups of criteria, sub criteria and characteristics of sub criteria (Lee 2009). Yong et al. (2005) proposed a model for selecting supplier by representing a compound method. They introduced a new approach to select supplier by the analytic hierarchy process and goal programming. Dacin and Hitt (1997) evaluated different criteria of selecting employed cooperator by the managers of Korean and American companies and provided some of the most important characteristics of relations between suppliers and companies in United States and Korea (Dacin \& Hitt 1997). Kannan and Tan (2003) assessed selection of supplier in United States and European countries by comparing US and European management (Kannan \& Tan 2003). Dempsi evaluated 20 criteria of selecting supplier in 1978 and defined them in two explicit and implicit groups. Dempsi thinks that the importance of selecting supplier is more than other parts of selecting supplier process. He believes that three factors are effective in selecting criteria and strategies of purchase (Karamshahi 2010). Table 1 shows arrangement of criteria for selecting supplier from Dempsi's view.

\section{Table 1}

Criteria of selecting from Dempsi view (1978)

\begin{tabular}{ll}
\hline Type of criterion & Criteria \\
\hline Explicit & $\begin{array}{l}\text { Ability of in time delivery, quality, price, repair, technical ability, previous } \\
\text { operation }\end{array}$ \\
Implicit & $\begin{array}{l}\text { Popularity, financial situation, similarity of working approaches, communications, } \\
\text { attitude of supplier }\end{array}$
\end{tabular}

There are many attempts for selecting supplier with different methods. Table 2 summarizes some of the most important ones with the technique. 
Table 2

Different techniques used for supplier selection

\begin{tabular}{|c|c|c|c|}
\hline Author & Technique & Author & Technique \\
\hline Dogan and Sahin (2003) & Fuzzy, ABC & Ghodsypour and O'Brien (1998) & AHP,MP \\
\hline Bevilacqua et al. (2006) & Fuzzy, QFD & Kokangul \& Susuz (2009) & AHP,MOP \\
\hline Gencer and Gürpinar (2007) & ANP & Yang and Chen (2005) & AHP, Grey approach \\
\hline Demirtas and Ustun (2008) & ANP, MOP, MIP & Ha and Krishnan (2008) & AHP, DEA \\
\hline Bottani and Rizzi (2006) & Fuzzy Topsis & Dahel (2003) & MOP \\
\hline Vindoh et al 2011 & Fuzzy ANP & Garfamy (2006) & DEA, TCO \\
\hline Sevkli et al 2007 & AHP-Fuzzy LP & Kumar et al 2004 & Fuzzy GP \\
\hline Bazzazi et al 2011 & Fuzzy VIKOR & Lopez 2007 & Expert systems \\
\hline Xia and Wu (2007) & AHP,MOP,MIP,RST & $\begin{array}{l}\text { Hong, Park, Jang, and Rho } \\
(2005)\end{array}$ & MIP,DM \\
\hline
\end{tabular}

Next, we propose a model by compounding analytic network technique and fuzzy goal programming to rank different suppliers.

\section{Methodology}

\subsection{Exploratory factor analysis}

Methodology is a collection of rules, instrument, valid and systematic methods for evaluating facts, detecting indefinites and achieving methods to handle difficulties. A collection of criteria and indices are gathered after reviewing literature and fulfilled research. Let $F_{j}, X_{i}$ and $W_{j i}$ be the factor of $i_{\text {th }}$, the variable $i_{\text {th }}$ and weight of the factors, respectively. Therefore we have,

$F_{j}=\sum W_{j i} X_{i}=W_{j 1} X_{1}+\ldots .+W_{j p} X_{p}$

The experts that used in this research are the whole managers whom are involved in decision making of purchasing in the case study of this paper. We choose executive, business managers, product managers and technical managers. We have designed a questionnaire consists of 30 questions and circulated among 240 people. The primary concern was to perform a factor analysis of 15 criteria where 4 principle factors were detected and the results are summarized in Table 3.

Kaiser-Meyer (KMO) test is 0.93 , which shows that the volume of sample is suitable for factor analysis. Bartlet test is used for the estimation of $\chi^{2}=1504.047$ and level of assurance (Sig) is lower than 0.05 that shows that factor analysis is suitable for recognizing structure. Cronbach's alpha based on standardized items was detected to .89 where the number of items was 30 and it indicates that our survey results are highly reliable. Table 3 shows the initial Communalities and extractive communion. Communalities of one variable are equivalent with square of multiple correlations regarding related variables by factors (as the predictor). All initial communions are equivalent with 1. In the initial factor analysis, 15 factors were extracted from 30 factors since the amount of extraction was less than 0.4 .

Table 3

Extraction Method: Principal Component Analysis

\begin{tabular}{|c|c|c|c|c|c|c|c|c|c|c|c|c|c|c|c|}
\hline Question & 1 & 2 & 3 & 4 & 5 & 6 & 7 & 8 & 9 & 10 & 11 & 12 & 13 & 14 & 15 \\
\hline Initial & 1 & 1 & 1 & 1 & 1 & 1 & 1 & 1 & 1 & 1 & 1 & 1 & 1 & 1 & 1 \\
\hline Extraction & .561 & .663 & .686 & .637 & .541 & & .561 & .472 & .712 & .788 & .723 & .739 & .63 & .608 & .744 \\
\hline
\end{tabular}


Terms of Q1 to Q15 show the criteria of research which will be presented in the next part as the structure of research model. The next output of factor analysis includes three parts having been brought in Table 3.

Table 4

The results of principal component analysis (PCA)

\begin{tabular}{|c|c|c|c|c|c|c|c|c|c|}
\hline \multicolumn{10}{|c|}{ Total Variance Explained } \\
\hline \multirow[t]{2}{*}{ Component } & \multicolumn{3}{|c|}{ Initial Eigenvalues } & \multicolumn{3}{|c|}{$\begin{array}{c}\text { Extraction Sums of Squared } \\
\text { Loadings } \\
\end{array}$} & \multicolumn{3}{|c|}{ Rotation Sums of Squared Loadings } \\
\hline & Total & Percent & Cumulative & Total & Percent & Cumulative & Total & Percent & Cumulative \\
\hline 1 & 6.029 & 40.193 & 40.193 & 6.029 & 40.193 & 40.193 & 4.009 & 26.729 & 26.729 \\
\hline 2 & 1.350 & 9.003 & 49.196 & 1.350 & 9.003 & 49.196 & 2.186 & 14.574 & 41.303 \\
\hline 3 & 1.151 & 7.671 & 56.867 & 1.151 & 7.671 & 56.867 & 1.754 & 11.692 & 52.995 \\
\hline 4 & 1.097 & 7.315 & 64.182 & 1.097 & 7.315 & 64.182 & 1.678 & 11.187 & 64.182 \\
\hline 5 & .849 & 5.660 & 69.842 & & & & & & \\
\hline 6 & .748 & 4.985 & 74.827 & & & & & & \\
\hline 7 & .592 & 3.949 & 78.776 & & & & & & \\
\hline 8 & .554 & 3.695 & 82.472 & & & & & & \\
\hline 9 & .496 & 3.308 & 85.779 & & & & & & \\
\hline 10 & .460 & 3.066 & 88.845 & & & & & & \\
\hline 11 & .421 & 2.804 & 91.648 & & & & & & \\
\hline 12 & .394 & 2.628 & 94.277 & & & & & & \\
\hline 13 & .346 & 2.308 & 96.585 & & & & & & \\
\hline 14 & .290 & 1.934 & 98.519 & & & & & & \\
\hline 15 & .222 & 1.481 & 100.000 & & & & & & \\
\hline
\end{tabular}

Table 4 consists of three parts, where the first one is associated with initial Eigen values and determines factors that remained in the analysis. Factors including special amounts and are lower than 1 have been removed from analysis. The second part of table shows explorative factors without rotation and the third part represents the extractive factors with rotation. In this research, factors of 1 , 2,3 , and 4 involved higher amount of 1 . These four factors can show $\% 64$ of variables' transition. Table 5 shows the rotated matrix of components that include factor loadings of every one of variables in the remained factors subsequent to rotation.

Table 5

Rotated components matrix

\begin{tabular}{|c|c|c|c|c|c|c|c|c|c|c|c|c|c|c|}
\hline \multirow[b]{2}{*}{ Component } & \multicolumn{14}{|c|}{ Question } \\
\hline & 1 & 2 & 3 & 4 & 5 & 7 & 8 & 9 & 10 & 11 & 12 & 13 & 14 & 15 \\
\hline 1 & .353 & .165 & .085 & -.016 & .207 & .317 & .447 & .792 & .848 & .820 & .802 & .734 & .286 & .144 \\
\hline 2 & .022 & .180 & .117 & .267 & .553 & -.094 & .313 & .264 & .130 & .124 & .204 & .238 & .721 & .825 \\
\hline 3 & .465 & -.02 & .132 & .752 & .436 & .665 & .411 & .097 & .116 & .099 & .212 & .167 & .041 & .035 \\
\hline 4 & .469 & .777 & .805 & .032 & .048 & .097 & .071 & .077 & .196 & .161 & .100 & .085 & .035 & .203 \\
\hline
\end{tabular}

Four extracted principle factors regarding literature of research is named as the following terms:

1) Production;

2) Human resources;

3) Organizational characteristics;

4) Evaluation of qualitative system.

Structural research model is determined with consideration of extracted factor loadings of Table 5 . Fig. 3 shows final model of research on the basis of validity structure of factor analysis. 


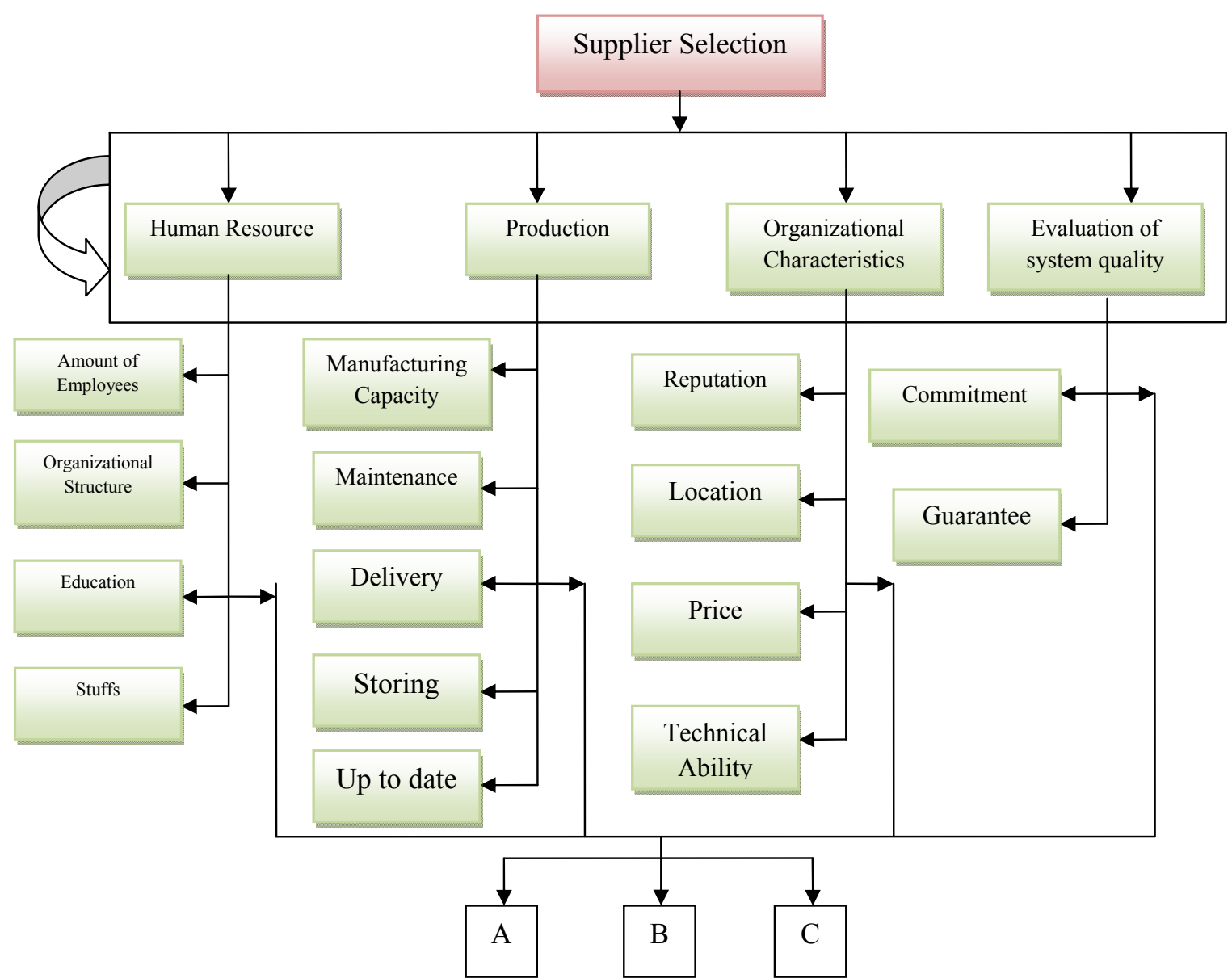

Fig. 3. Model of research for the supplier selection

The other arrows in the second level of model shows relations of principle factors being achieved from factor analysis and will be used in the next section for pairwised comparison in analytical network process

\section{Analytical network process}

In the fulfilled premier researches, process of hierarchy analysis is used to solve complex decision matters as a multi criteria decision technique. Saaty (1980) introduced AHP for the first time and used it to solve complex matters (Kahraman et al., 2006). Principle assumption in AHP is the independency of higher levels towards lower levels, criteria and other factors in every level. Most of decision makers are not organized hierarchically due to bilateral relationships among different factors (Saaty, 1996). In AHP, relationships among indices and levels of decision making are bilateral. Hence, hierarchical structure with a linear relation towards below is not suitable for a complex system. Process of analytical network process (ANP) model making is described in three steps (Onut et al. 2009):

Step 1: Pairwised comparisons and estimation of relations' weight and Likerd scale given in Table 6. 
Table 6

Linguistic terms for different definitions, Saaty's Scales (Onut et al 2009)

\begin{tabular}{|c|c|c|c|c|c|c|c|}
\hline Scale & 1 & 3 & 5 & 7 & 9 & $2,3,6,8$ & \\
\hline Definition & Equal & $\begin{array}{ll}\text { A } & \text { few } \\
\text { important } & \end{array}$ & Important & Very important & $\begin{array}{l}\text { Extremely } \\
\text { important }\end{array}$ & $\begin{array}{l}\text { Between the } \\
\text { definitions }\end{array}$ & ove \\
\hline
\end{tabular}

The proposed model of this paper uses AHP to rank various alternatives (Yuksel \& Dagdeviren 2007).

\section{Hybrid model of analytic network and fuzzy-goal programming}

\subsection{Fuzzy-goal programming model}

Zadeh and Bellman (1970) presented a fuzzy method for decision making in the fuzzy environment (uncertainty, ambiguous environment). Then Zimmerman (1978) presented a method for solving multi objective functions. Here, we want to present a general fuzzy multi objective model for improved selection of suppliers. The proposed model maximizes the suppliers' utilities, $X=\left[X_{1}, X_{2} \ldots, X_{n}\right]$, in a fuzzy form by considering different restrictions with the following form,

$\max \tilde{Z}=\sum_{i=1}^{n} C_{k i} X_{i} \geq Z_{k}^{0} \quad k=1, \cdots, m$

subject to

$\sum_{i=1}^{n} a_{r i} \times X_{i} \leq b_{r}$

where $C_{k i}, a_{r i}$ and $b_{r}$ are the crisp amounts. Sign of $(\sim)$ shows fuzzy environment in this model. In addition, $Z_{k}^{0}$ is a suitable level so that decision makers tend to achieve and $\tilde{Z}$ is defined as follows,

$\tilde{Z}=\left\{\begin{array}{cc}1 & \text { for } Z_{k} \geq Z_{k}^{\max } \\ \frac{Z_{k}^{\max }-Z_{k}(x)}{Z_{k}^{\max }-Z_{k}^{\min }} & \text { for } Z_{k}^{\min }<Z_{k}<Z_{k}^{\max } \\ 0 & \text { for } Z_{k} \leq Z_{k}^{\min }\end{array}\right.$

In this process, a linear function is achieved by multiplying fuzzy goal with its important weights (Sakawa, 1993) that is equivalent with accounting method of Zirman (1978).

$\max \sum_{k=1}^{m} \lambda_{k} W_{k}$

subject to

$\lambda_{k} \leq \mu_{z k}(X)$,

$\lambda_{k} \in[0,1]$ and $k=1, \cdots, m$

$\sum_{k=1}^{m} W_{k}=1, \quad W_{k} \geq 0$

$X_{i} \geq 0, \quad i=1, \cdots, n$.

\section{Case Study}

In this section, we present the implementation of our proposed hybrid method for a real-world case study of auto part makers. In our study, we have chosen four attributes of human resources, production, quality system evaluation and organizational characteristics as four major factors detected 
in the previous section and they are ranked using AHP. Table 7 summarizes the details of our pairwise comparison.

\section{Table 7}

The ranking of three suppliers according to four attributes based ANP

\begin{tabular}{lllll}
\hline & \multicolumn{3}{c}{ Attributes } \\
\cline { 2 - 5 } Supplier & $\begin{array}{l}\text { Human } \\
\text { Resource }\end{array}$ & Production & $\begin{array}{l}\text { Evaluation of quality of } \\
\text { system }\end{array}$ & $\begin{array}{l}\text { Organizational } \\
\text { characteristics }\end{array}$ \\
\hline A & 0.270 & 0.123 & 0.196 & 0.160 \\
B & 0.406 & 0.649 & 0.528 & 0.367 \\
C & 0.323 & 0.226 & 0.275 & 0.472 \\
Final Weight & 0.472 & 0.108 & 0.256 & 0.164 \\
\hline
\end{tabular}

Using the information of Table 7 we build the following multi objective linear programming model.

$\max Z_{1}=0.270 x_{1}+0.406 x_{2}+0.323 x_{3}$

$\max Z_{2}=0.123 x_{1}+0.649 x_{2}+0.226 x_{3}$

$\max Z_{3}=0.196 x_{1}+0.528 x_{2}+0.275 x_{3}$

$\max Z_{4}=0.160 x_{1}+0.367 x_{2}+0.472 x_{3}$

subject to

$x_{1}+x_{2}+x_{3}=1$

$x_{1}, x_{2}, x_{3} \geq 0$.

The $Z_{k}^{\min }$ and $Z_{k}^{\max }$ for this case study are summarized in Table 8 .

\section{Table 8}

Data Collection for the membership function

\begin{tabular}{lllll}
\hline $\begin{array}{l}\text { Effective } \\
\text { Factors }\end{array}$ & $\mathrm{Z}_{2}=$ Production & $\begin{array}{l}\mathrm{Z}_{4}=\text { Evaluation } \\
\text { quality of system }\end{array}$ & of & $\begin{array}{l}\mathrm{Z}_{3}=\text { Organizational } \\
\text { characteristics }\end{array}$ \\
\hline$Z_{k}^{\text {Min }}(\mu=0)$ & 0.123 & 0.196 & 0.160 & $\mathrm{Z}_{1}=$ Human Resource \\
$Z_{k}^{\text {Max }}(\mu=1)$ & 0.649 & 0.528 & 0.472 & 0.270 \\
\hline
\end{tabular}

$\max Z=0.472 \lambda_{1}+0.108 \lambda_{2}+0.256 \lambda_{3}+0.164 \lambda_{4}$

subject to

$$
\begin{aligned}
& \lambda_{1} \leq \frac{0.406-\left(0.406 x_{1}+0.323 x_{2}+0.270 x_{3}\right)}{0.406-0.270} \\
& \lambda_{2} \leq \frac{0.649-\left(0.649 x_{1}+0.226 x_{2}+0.123 x_{3}\right)}{0.649-0.123} \\
& \lambda_{3} \leq \frac{0.528-\left(0.528 x_{1}+0.275 x_{2}+0.196 x_{3}\right)}{0.528-0.196} \\
& \lambda_{4} \leq \frac{0.472-\left(0.472 x_{1}+0.367 x_{2}+0.160 x_{3}\right)}{0.472-0.160}
\end{aligned}
$$

$\lambda \in[0,1]$ 
The implementation of any linear programming software package yields $x_{1}^{*}=0, x_{2}^{*}=0, x_{3}^{*}=1$. As a result, we can conclude that supplier 3 (C) should be selected based on decision makers preferable ideas with $f_{1}=1, f_{2}=0, f_{3}=1$ and $f_{4}=0$ with $\lambda_{1}=0.45 \lambda_{2}=0.1 \lambda_{3}=0.35$ and $\lambda_{4}=0.1$. Based on the results we have calculated human resource management and organizational structure play important roles on our decision-making. We have compared the performance of our hybrid ANP-FGM method with ANP and the results are compared in Table 9.

\section{Table 9}

The results of comparison between ANP-FGM and ANP method

\begin{tabular}{lcc}
\hline & ANP- FGM & ANP \\
\hline A & 0 & 0.339 \\
B & 0 & 0.365 \\
C & 1 & 0.260 \\
\hline
\end{tabular}

\section{Conclusions}

In this paper, we have presented a comprehensive method to choose appropriate alternative among different choices where all criteria are under uncertainty. We first performed a factor analysis to determine the most important criteria for selection of an auto part maker. We have set up a questionnaire consist of 15 questions and distributed among top level managers who were involved in decision making. The results have indicated that human resource, production, quality and organizational characteristics played important role on selection strategy. The hybrid model used in this paper implemented analytical network process to rank different part maker suppliers and fuzzy goal programming to choose the appropriate alternative among various choices. The implementation of the proposed model of this paper has been used for a case study of real-world problem and the results have been compared with pure ANP method.

\section{References}

Aissaoui, N., Haouari, M., \& Hassini, E. (2007). Supplier selection and order lot sizing modeling: A review. Computers \& Operations Research, 34, 3516-3540.

Amid, A., Ghodsypour, S.H., \& O’Brien, C. (2006). Fuzzy Multiobjective linear model for thesupplier selection in a supply chain. International Journal of Production Economics, 104, 394407.

Amin, S. H., \& Razmi J. (2009). An integrated fuzzy model for supplier management: A case study of ISP selection and evaluation. Expert system with applications, 36, 8639-8648.

Bellman, R.G., \& Zadeh, L. A. (1970). Decision making in a fuzzy environment. Management Science, 17(2), 141-164.

Bevilacqua, M., Ciarapica, F. E., \& Giacchetta, G. (2006). A fuzzy-QFD approach to supplier selection. Journal of Purchasing and Supply Management, 12(1), 14-27.

Bottani, E., \& Rizzi, A. (2006). A fuzzy TOPSIS methodology to support outsourcing of logistics services. Supply Chain Management: An International Journal, 11(4), 294-308.

Chandra, C., \& Kumar, S. (2000). Supply chain management in theory and practice: a passingfad or a fundamental change? Industrial Management \& Data Systems, 100(3), 100-113.

Chou, S. Y., \& Chang, Y. H. (2008). A decision support system for supplier selection based on a strategy-aligned fuzzy SMART approach. Expert Systems with Applications, 34(4), 2241-2253.

Dacin, M. T., \& Hitt, M. A. (1997). Selecting partners for successful international alliances: Examination of US and Korean firms. Journal of World Business, 32(1), 3-16.

Dahel, N. E. (2003). Vendor selection and order quantity allocation in volume discount environments. Supply Chain Management: An International Journal, 8(4), 335-342. 
Deagraeve, Z., Labro, E., \& Roodhooft, F. (2000). An evaluation of vendor selection models from a total cost of ownership perspective. European Journal of Operational Research, 125, 34-58.

Dogan, I., \& Sahin, U. (2003). Supplier selection using activity-based costing and fuzzy present worth techniques. Logistics Information Management, 16(6), 420-426.

Garfamy, R. M. (2006). A data envelopment analysis approach based on total cost of ownership for supplier selection. Journal of Enterprise Information Management, 19(6), 662-678.

Ghodsypour, S. H., \& O’Brien, C. (1998). A decision support system for supplier selection using an integrated analytic hierarchy process and linear programming. International Journal of Production Economics, 56-57(1-3), 199-212.

Hartley, J. L., \& Choi, T. Y. (1996). Supplier development: customer as a catalyst of process change. Business Horizons, 39(4), 37-40.

Hull, B., Patell, S. \& Williams, S. (1999). Taming the supply chain. Manufacturing Engineering, 78(2), 68-72.

Hong, G. H., Park, S. C., Jang, D. S., \& Rho, H. M. (2005). An effective supplier selection method for constructing a competitive supply-relationship. Expert Systems with Applications, 28(4), 629639.

Kannan, V. R., \& Tan, K. C. (2003). Attitudes of US and European managers to supplier selection and assessment and implications for business performance. Benchmarking: An International Journal, 10(5), 472-489.

Kahraman, C., Cebeci, U. \& Ulukan, Z. (2003). Multi criteria supplier selection using fuzzy AHP. Logistics Information Management, 16(6), 382-394.

Kahraman, C., Cebeci, U., \& Ruan, D. (2004). Multi-attribute comparison of catering service companies using fuzzy AHP: the case of Turkey. International Journal of Production Economics, 87, 171-184.

Koh, S. C. L. \& Tan, K. H. (2006). Translating knowledge of supply chain uncertainty into business strategy and actions. Journal of Manufacturing Technology Management, 17(4), 472-85.

Koh, S.C.L., Demirbag, M., Bayraktar, E., Tatoglu, E. \& Zaim, S. (2007). The impact of supply chain management practices on performance of SMEs. Industrial Management \& Data Systems, 107(1), 103-124.

Lee, A. H. I. (2009). A fuzzy supplier selection model with the consideration of benefits, opportunities, costs and risks. Expert Systems with Applications, 36, 2879-2893.

Lin, C.-W. R., \& Chen, H.-Y. S. (2004). A fuzzy strategic alliance selection framework for supply chain partnering under limited evaluation resources. Computers in Industry, 55, 159-179.

Lopez, R. F. (2007). Strategic supplier selection in the added-value perspective: A CI approach. Information Sciences, 177(5), 1169-1179.

McCutcheon, D., \& Stuart, F. I. (2000). Issues in the choice of supplier alliance partners. Journal of Operations Management, 18, 279-301.

Mikhailov, L. (2002). Fuzzy analytical approach to partnership selection in formation of virtual enterprises. Omega: The International Journal of Management Science, 30, 393-401.

Oliveria, R. C. \& Lourenco, J. C. (2002). A multicriteria model for assigning new orders to service suppliers. European Journal of Operational Research, 139, 390-399.

Önüt S., Kara, S. S., Isik, E. (2009). Long term supplier selection using a combined fuzzy MCDM approach: A case study for a telecommunication company. Expert Systems with Applications, 36, 3887-3895.

Saaty, T. L., \& Vargas, L. G. (1998). Diagnosis with dependent symptoms: Bayes theorem and the analytic network process. Operations Research, 46(4), 491-502.

Saaty, R. W. (2003). Decision making in complex environment: The analytic hierarchy process (AHP) for decision making and the analytic network process (ANP) for decision making with dependence and feedback. $<w w w . S u p e r d e c i s i o n s . c o m />$. 
Saaty, T. L. (2004). Fundamentals of the analytic network process multiple networks with benefits, opportunities, costs and risks. Journal of Systems Science and Systems Engineering, 13(3), 348379.

Sakawa, M. (1993), Fuzzy Sets and Interactive Multiobjective Optimization, Plenum Press,New York, NY.

Sevkli, M., Lenny, K.S.C., Zaim, S., Demirbag, M., \& Tatoglu, E. (2008). Hybrid Analytical Hierarchy Process Model for Supplier Selection. Industrial Management \& Data Systems, 108(1), 122-142.

Spekman, E.R., Kamauff, J.W. Jr., \& Myhr, N. (1998). An empirical investigation into supply chain management. International Journal of Physical Distribution \& Logistics Management, 28(8), 630650.

Shahanaghi, K. \& Yazdian, S. A. (2008). vendor selection using a new fuzzy group TOPSIS approach. Journal of Uncertain System. 3(3), 221-231.

Stevenson, W. J. (2002). Operation Management, $7^{\text {th }}$ edition, Mc Graw Hill.

Vinodh, S., Ramiya, R. A., \& Gautham S. G. (2011). application of fuzzy analytic network process for supplier selection in a manufacturing organization, Expert System with Applications, 38,272280.

Xia, W., \& Wu, Z. (2007). Supplier selection with multiple criteria in volume discount environments. Omega, 35(5), 494-504.

Yan, H., Yu, Z., \& Cheng, T.C.E. (2003). A strategic model for supply chain design with logical constraints: formulation and solution. Computers \& Operations Research, 30, 2135-2155.

Yang, J. L., Chiu, H. N., Tzeng, G. H., \& Yeh, R. H. (2008). Vendor selection by integrated fuzzy MCDM techniques with independent and interdependent relationships. Information Sciences 178, 4166-4183.

Yazgan, H. R. (2010). Selection of dispatching rules with fuzzy ANP approach. International journal of advance manufacturing. 170, 2739-2747.

Yüksel, I, \& Dagdeviren, M. (2007). Using the analytic network process (ANP) in a SWOT analysis - A case study for a textile firm. Information Sciences, 177(16), 3364-3382.

Yuksel, I., Dagdeviren, M. (2007). A fuzzy analytic network process (ANP) model for measurement of the sectoral competititon level (SCL). Expert Systems with Applications. 37(2), 1005-1014.

Zimmermann H.J. (1978). Fuzzy programming and linear programming with several objective functions. Fuzzy sets and systems, 1, 45-55. 